\title{
Quality of life after traumatic loss and the role of social support - examining the psychological consequences of the war twenty-five years later ${ }^{1}$
}

\section{Sanja Radetić Lovrić ${ }^{2}$}

University of Banjaluka, Department of psychology, Faculty of Philosophy

\author{
Aleksandra Pećanac \\ Nova banka, a.d. Banja Luka
}

\begin{abstract}
Summary: The research was conducted with the aim of understanding the farreaching psychological consequences of the war that took place in the territory of former Yugoslavia (1991-1995). The study examines the relationships between wartime traumatic experience of loss, the quality of life and mental health, and the role of social support across three categories of respondents: the first consisting of the respondents who had lost a close family member in the war and whose remains have not been found to date; the second category consisting of the persons who had lost a close family member in the war, and the third category including the respondents who participated in the war socialization but did not experience the loss of a close family member in the war. The survey used the Psychosomatic symptoms lists, the Depression Symptoms Questionnaire, the Subjective Happiness Scale, the Life Satisfaction Scale, and the Social Support Significance Assessment Scale. The results show that the respondents who continue to search for the body of a missing family member have a lower quality of life than the other two categories of respondents, as well as a more pronounced presence of depressive and psychosomatic symptoms. The role of social support in the trauma recovery process remains unclear. The results of the study are discussed in relation to completed and prolonged traumatic loss, and point to further research into the complex emotional dynamics as a consequence of war socialization and the importance of professional psychological support.
\end{abstract}

Keywords: traumatic loss, quality of life, social support, missing persons

1 This research was supported by The International Committee of the Red Cross

2 sanja.radetic-lovric@ff.unibl.org 


\section{Introduction}

The civil war in Bosnia and Herzegovina, which took place between 1992 and 1995, left many consequences behind. Objective consequences are visible to the naked eye and are evident in the number of casualties and civilians killed, settlements destroyed, the economy, poverty, poor living conditions and the like (Milosavljević, 2000, 2003). On the other hand, psychological, subjective consequences have been present for years after the war has been over and are much harder to repair. They remain hidden deep within the human being, are difficult to see, and are not as visible and measurable. Culturally, we tend not to worry about our mental health, and we put aside the subjective consequences of stressful and traumatic experiences. The subjective consequences of life in wartime suggest that formally ending a war does not mean ending it psychologically. Many of the experiences that people were faced with entailed uncertainty, fear for their own lives, struggles for existence, escape, leaving behind everything that had previously been gained in life. The lived wartime experiences cannot be erased from human memory. They remain permanently recorded in recollection (Milosavljević, 2003). Such memories do not cease when the war has formally ended, but continue to be sustained through cognitive processes, affecting emotional states and the behaviours of those who have experienced aversive experiences(Alexander et al., 2004; Fonagy and Allison, 2014; Haskel and Randall, 2009; Hutchinson \& Bleiker, 2015).

It is assumed that the subjective consequences of war are the most pronounced for those who have suffered the most intense stressors -such as the loss of their loved ones (Boss, 2002; Bowen, 1991; Hadžić, 2019; Hamburger et al., 2018). In particular, especially traumatic experiences are specific to those families whose close members are reported missing and there is no information available to date, twenty-five years later, about what happened to them. The inability to find their remains makes the grieving process very complex, affecting their daily lives, their recovery from loss and constantly reminding them of and making them confront war stressors. For these people, in the psychological sense, the war is not over. It is estimated that there are over 6000 families in Bosnia and Herzegovina (B\&H) that have been waiting for more than two decades to find out what happened to their loved ones (International Committee of the Red Cross, 2019). This research is an attempt to point out the importance of the subjective consequences of war and the thesis that formally ending a war for the persons who experienced specific circumstances of life and socialization during the war does not necessarily imply ending it in psychological terms, even after more than two decades after the formal cessation of the armed conflict. 


\section{Traumatic experience of losing a loved one}

Unexpected and sudden death, as in wartime, leads to trauma, and this trauma itself is further aggravated by the overall experience of life during the wartime. Grieving has a significant function of saying goodbye to a loved one and should, according to theoretical concepts, reduce pain and suffering, and help people to continue with their lives after the death of a loved one (Buckman, 1996).

The issue of mourning for the deceased and for the missing persons can be related to Bolby's concept of affective attachment (Bowlby, 1969). Affective attachment is a defence system of an individual. If left without a close person, without a figure of attachment, the individual is left without protection and security, which is one of the basic human needs, a biological and psychological mechanism related to the survival of the species (Bowlby, 1969). The process of mourning after the death of a loved one involves breaking the bond with a loved one and building a space to establish new forms of bonding. However, in the case of person's disappearance and a lack of accurate information about his or her death, the decision to sever the affective connection with the missing person becomes dramatic and represents additional trauma. Families seeking information about their missing members continue to maintain an affective attachment to the missing person, burdened with uncertainty, hope, thoughts in which they reconstruct events and information, and wonder what kind of world it is in which people disappear and no one knows the exact information about them. Such subjective experiences generate complex emotional dynamics, which delays the acceptance of the fact that the missing person is not present in their lives, delays the beginning of the grieving process, and may even cause guilt due to the acceptance of grieving for someone who has not been found or due to not believing in the identification of the recovered remains (Hutchinson \& Bleiker, 2015). Delaying the grieving process in cases of missing persons is also embedded in social trauma, which has become a part of social identity and cultural heritage (Alexander et al., 2004; Haskell \& Randall, 2009; Pedović \& Hedrih, 2019). Social trauma is a relatively new concept in psychological literature, but research related to the consequences of war suggests the justification of its study (Alexander et al., 2004; Hamburger et al., 2018; Haskell \& Randall, 2009; Pedović \& Hedrih, 2019). According to Haskell and Randall (2009), social trauma is a complex trauma and a collective emotional wound experienced by a particular social community and, as such, can be embedded in the cultural heritage of the said community and passed on to future generations. Bjornsson and co-workers (2020) have found that people who suffer from social trauma also suffer more from anxiety and depressive symptoms, and they are more likely to develop the post-traumatic stress disorder. 
While, on the one hand, the post-war social communities want to forget the horrors of war as soon as possible and move on with life, on the other hand, they paradoxically, simultaneously and continuously maintain the memories of losses, war violence and injustices committed (Hutchinson and Bleiker, 2015). In this way, the horrors of war socialization are built into "collective memories", and socio-political life in a community takes on emotional factors, as a result of which the pain and suffering of those who experienced war trauma (e.g. lost their loved ones) enter a vicious circle of uncertainty, maintaining social trauma and its cultural transmission from generation to generation (Pedović and Hedrih, 2019).

Cultural rituals and the support system of the loved ones facilitate the grieving process to some extent (Betz and Thorngren, 2006). However, what happens when people have no information about the loved one who is reported missing? Boss (1999) calls this kind of loss of a close person an "ambivalent loss". The "ambivalent loss" is characterized by uncertainty and lack of information about whether or not a loved one is alive and what really happened to them. The situation of uncertainty due to the lack of information greatly complicates the grieving process, as it prevents the practice of rituals that assist in going through the grieving process, but also burdens cognitive processes with many unanswered questions (e.g. ritual burials, conflicting information of witnesses who last saw the person, previous information). The situation of uncertainty often lasts until the missing person has been found, which in some cases never happens. Years after the disappearance of a loved one, families are preoccupied with memories of the individual, thinking about the reasons, possibilities, possible scenarios of disappearance, their suffering, or hoping that the loved one is alive, perhaps in some other better place (Boss, 2002).Often, people are left with no recourse but to construct their own truth about the missing person, and shortly thereafter reconstruct it, because without official, verified and proven information, this story will never get closure. People often deny themselves the right to mourn because they have never actually received confirmation that the missing person is no longer alive (Werner-Lin and Moro, 2004). This kind of loss makes it impossible to perform rituals that are of great cultural importance for resolving the loss, beginning and progressing through the stages of an adaptive grief process. If the case remains unresolved for a long period, it becomes extremely physically and mentally exhausting. For all of these reasons, the mental health of close family members of missing persons can be very vulnerable and susceptible to symptoms of depression, anxiety and psychosomatic disorders. Trauma impairs trust in the environment, in the relationships with other people, and leads to a state of helplessness, essentially having a negative effect on all aspects of human life and activity and thus impairing the quality of life and psychophysical health of people (Hadžić, 2019). 


\section{Social support and quality of life after traumatic loss}

Social support is one of the most important protective factors in dealing with trauma and it is closely linked to positive outcomes when it comes to psychological and physical health (Zvizdić, 2015). Social, professional and economic support and rehabilitation are necessary if we are to expect people to recover from the adverse effects of war (Başoğlu et al., 2005). When they have support, people feel much safer and more secure. Social support greatly mitigates the physical and psychological consequences of exposure to stress (Thoits, 2011). Keilson and Sarphatie (1992) state that the impact of traumatic experience on the person's development depends on the presence or lack of psychosocial support in the environment after the traumatic event that caused the traumatic process. If we receive support in the form of understanding and compassion in interpersonal relationships, it is easier to deal with traumatic experiences in comparison to the situations where we find ourselves misunderstood by the environment. Social support is first and foremost expected from close people, most often family, and then from professionals and the community. For the people who have experienced the loss of a loved one, emotional support is of paramount importance (Lakey and Cohen, 2000), and the longest and most enduring assistance can be obtained through family support (Heaney and Israel, 2008).

In certain situations, the adverse effects of experienced war stressors and traumatic experiences produce maladaptive conditions and behaviours that go beyond the capacity of the family support itself. In these cases, professional support is also needed. Research shows that people who had returned from the battlefield and did not have support from their family had a greater chance of prolonged traumatic symptoms, while those with the post-traumatic stress disorder distanced themselves from their loved ones (Frye and Stockton, 1982).It is very important for the people who are traumatized that their trauma gets recognized and that the society makes an effort to help them find the missing family members. According to Herman (2012), this is the only way for people to regain the impression of a just world. However, overemphasizing traumatic experiences can have the opposite effect and lead to the deepening of hatred between the warring parties, reducing the chances of forgetting, forgiveness and coexistence.

\section{Research problem and aim}

The social changes that occur within the framework of wartime socialization (e.g. population migration, refugees, shelling, murders, missing persons) affect the psychological state of individuals and their families and contribute to the loss of trust in the world around them. They are embedded as life 
experiences in the psychological framework of the individual and transmitted as cultural heritage of families (Batista-Pinto Viese, 2010). The transmission of traumatic experiences within family dynamics can affect the occurrence of unfavourable patterns of affective attachment and patterns of social relations (Pedović \& Hedrih, 2019), but it can also lead to impaired mental health of parents, whose mental suffering and pain gained through experiences of wartime socialization leaves a mark on the mental health of their children (Hadžić, 2019; Haskell \& Randall, 2009). A dramatic breakdown of affective attachment and "ambivalent" traumatic loss create psychological suffering that leaves its mark on the quality of life and requires social support. Having in mind the above, in this research we examine the relationships between the traumatic loss of a loved one during war, mental health, quality of life and the role of social support in the sample of respondents who experienced wartime socialization in the former Yugoslavia in the first half of the 1990s. Special emphasis in the research isplaced on the existence of differences in relation to the experienced traumatic loss of a loved one who died in the war and a person whose remains were not found.

We assumed that respondents still searching for close family members who perishedor disappeared during the war would have a lower rate of quality of life and more aspects of disruption of mental health compared to the respondents who have found and buried the remains of their loved ones, as well as compared to those who participated in the wartime society but did not experience the loss of a loved one during the war (Boss, 1999, 2002; Bowlby, 1969; Buskman, 1996). As social support can significantly contribute to recovery from loss, we assumed that it would be positively related to a better quality of life and less present symptoms of impaired mental health (Hadžić, 2019; Lakey \& Cohen, 2000; Zvizdić, 2015). The quality of life in this study isviewed through the experience of subjective happiness and life satisfaction, while the aspect of mental health isseen in the presence of psychosomatic symptoms and the symptoms of depression.

\section{Method}

\section{Sample and procedure}

The study comprised 299 respondents, divided into three sub-samples:

1. Respondents who lost a close family member in the war and the remains of the missing person have not been found to date (Respondent group "FM"-family of the missing), N (FM) = 100;

2. Respondents who lost a close family member in the war and the remains of the injured person were found and buried (Respondent group "FD"- family of the deceased), N (FD) = 100; 
3. Respondents who lived in the wartime companionship but did not lose any close family members (Respondent group "NL"- no loss), $\mathrm{N}(\mathrm{NL})=99$.

The average age of the total sample was $M=55.82$, and $49.5 \%$ of male respondents were surveyed in the total sample. Sample structure of respondents is shown in Table 1.

Table 1. Respondent Sample Structure

\begin{tabular}{lllccc}
\hline Group & & & $\mathrm{NL}$ & $\mathrm{FD}$ & $\mathrm{FM}$ \\
Variable & Category & Statistic & $(\mathrm{N}=99)$ & $(\mathrm{N}=100)$ & $(\mathrm{N}=100)$ \\
\hline Sex & male & $\mathrm{f} / \%$ & $58 / 58.6$ & $43 / 43.0$ & $47 / 47.0$ \\
& female & $\mathrm{f} / \%$ & $41 / 41.4$ & $57 / 57.0$ & $53 / 53.0$ \\
\hline Age & Descriptivestatistic & $\mathrm{AS}$ & 55.25 & 55.10 & 57.10 \\
& subgroup & $\mathrm{SD}$ & 10.55 & 14.19 & 13.99 \\
& & $\mathrm{Min}$. & 29 & 25 & 25 \\
& & $\mathrm{Max}$. & 77 & 82 & 81 \\
\hline Residence & rural & $\mathrm{f} / \%$ & $57 / 57.6$ & $24 / 24.0$ & $30 / 30.0$ \\
& urban & $\mathrm{f} / \%$ & $16 / 16.2$ & $51 / 51.0$ & $38 / 38.0$ \\
& suburban & $\mathrm{f} / \%$ & $26 / 26.3$ & $25 / 25.0$ & $32 / 32.0$ \\
\hline Education & primary & $\mathrm{f} / \%$ & $19 / 19.2$ & $18 / 18.0$ & $32 / 32.0$ \\
& secondary & $\mathrm{f} / \%$ & $60 / 60.6$ & $70 / 70.0$ & $60 / 60.0$ \\
& higher & $\mathrm{f} / \%$ & $20 / 20.2$ & $12 / 12.0$ & $8 / 8.0$ \\
\hline Marital Status & unmarried & $\mathrm{f} / \%$ & $29 / 29.3$ & $18 / 18.0$ & $14 / 14.0$ \\
& married & $\mathrm{f} / \%$ & $51 / 51.5$ & $37 / 37.0$ & $43 / 43.0$ \\
& divorced & $\mathrm{f} / \%$ & $6 / 6.1$ & $3 / 3.0$ & $14 / 14.0$ \\
& widow(er) & $\mathrm{f} / \%$ & $13 / 13.1$ & $42 / 42.0$ & $29 / 29.0$ \\
\hline Employment & employed & $\mathrm{f} / \%$ & $44 / 44.4$ & $48 / 48.0$ & $42 / 42.0$ \\
Status & unemployed & $\mathrm{f} / \%$ & $34 / 34.4$ & $16 / 16.0$ & $22 / 22.0$ \\
& retired & $\mathrm{f} / \%$ & $21 / 21.2$ & $36 / 36.0$ & $36 / 30.0$ \\
\hline Kinship with & spouse & $\mathrm{f} / \%$ & - & $35 / 35.0$ & $27 / 27.0$ \\
& parent & $\mathrm{f} / \%$ & - & $17 / 17.0$ & $40 / 40.0$ \\
& child & $\mathrm{f} / \%$ & - & $25 / 25.0$ & $23 / 23.0$ \\
& sibling & $\mathrm{f} / \%$ & - & $23 / 23.0$ & $10 / 10.0$ \\
\hline
\end{tabular}

FM - family of the missing; FD - family of the deceased; NL - no loss

The survey was conducted individually and anonymously, and all respondents voluntarily agreed to participate in the survey. One part of the research was conducted at the premises of the Republic Organization of the Families of the Captured and Killed War Veterans and Missing Civilians of the Republic of Srpska. The second part was conducted at the respondents' family homes, while the third part was conducted with the assistance of the local organizations of the families of the captured and killed war veterans and missing civilians throughout the territory of the Republic of Srpska. 
Parts of the questionnaires for the first two categories of respondents were sent by e-mail to the addresses of local organizations, which invited volunteer participants and then returned them to our address. This form of data collection was applied due to resource and time constraints.

\section{Instruments}

In addition to the questions on socio-demographic data, the battery contained the following items:

The Subjective Happiness Scale- SHS (Lyubomirsky and Lepper, 1999) contains 4 items that measure how much a person feels (un)happy; the answer is provided on a seven-point Likert-type scale. The study used a validated version of the scale by Jovanovic (2016). In our study, the internal consistency was $\alpha=.90$.

The Life Satisfaction Scale- SWLS (Diener, Emmons, Larsen, \& Griffin, 1985) consists of 5 items; the answers provided on a seven-point Likert-type scale. The scale is intended to measure the cognitive aspect of the quality of life, global life satisfaction, the level of achievement of meaningful goals, personal experience of oneself, as well as satisfaction with living conditions. The reliability of the scale, measured by the Kronbach's alpha coefficient, is $\alpha=.89$.

The List of Psychosomatic Symptoms -PSS (Subotic, 2014) includes 17 items that measure the prevalence of a variety of health symptoms and difficulties that may have a psychosomatic background. Representation is estimated over the past month and items are answered using a Likert scale ranging from 0 (none) to 3 (a lot). In our study, the internal consistency was $\alpha=.93$. Some of the symptoms from the list include insomnia, dizziness, poor concentration etc. In our study, internal consistencies were satisfactory. The instrument was created and validated on a non-clinical sample (Subotić, 2014).

PHQ-9 (The Patient Health Questionnaire) or the validated Serbian version of the questionnaire (Kroenke and Spitzer, 2002; Kroenke et al. 2001, validation Subotic, 2014) contains nine symptoms of depression according to DSM-IV and DSM-V criteria. Using a Likert-type scale, the respondents reported how often from 0 (not at all) to 3 (almost every day) these symptoms had been present during the previous two weeks. In our study, the internal consistency was $\alpha=.89$. Some of the symptoms of the scale comprise low interest or low satisfaction in daily activities, feeling tired or low energy, too low or too high appetite. The questionnaire is intended for use in the general population to screen for possible depressive difficulties (Subotić, 2014). 
The List of Social Support Received was constructed for the purposes of this research, with the aim of examining the extent of various forms of support received by the families of the dead and missing from the period of loss to the present, as well as the importance that the received support had for individuals. Some of the types of social support included in the list are the support from immediate family members, support from relevant institutions, professional and expert support etc.

\section{Data Analysis}

The relationship between the quality of life (viewed through the experience of subjective happiness and life satisfaction) in different categories of subjects with regard to the experienced loss was checked by the variance analysis procedure. The role of social support was tested using the multiple regression analysis procedures. The relationship between psychosomatic and depression symptoms was analysed through the use of the Kruskal-Wallis test. Statistical data processing was performed with the help of the open source R Deducer software package.

\section{Results}

The quality of life, measured through the experience of subjective happiness and life satisfaction in the three subcategories of respondents, was tested by Analysis of Variance (ANOVA).The results indicate that there are significant differences in life satisfaction $(\mathrm{F}(2,296)=44.67 ; \mathrm{p}<.001)$ and experienced subjective happiness $(\mathrm{F}(2,296)=35.59$; $\mathrm{p}<.001)$ depending on the category of loss of a close person (Table 3 ). Respondents who did not experience the loss of a close family member during the war have the highest life satisfaction on the average and show the highest degree of subjective happiness, while family members of the missing persons in the war have significantly the lowest life satisfaction and the lowest level of subjective happiness (Table 2 and Table 3 ).

Table 2.

Descriptive characteristics of life satisfaction, subjective happiness, depression and psychosomatic symptoms

\begin{tabular}{lcrrrrrrrr}
\hline Variable & N & \multicolumn{1}{c}{ AS } & \multicolumn{1}{c}{ Med } & \multicolumn{1}{c}{ Mod } & SD & \multicolumn{1}{l}{ Sk } & Ku & Min. & \multicolumn{1}{c}{ Max. } \\
\hline Life Satisfaction & 299 & 17.30 & 17.00 & 10.00 & 7.32 & .28 & -.68 & 5.00 & 35.00 \\
Subjective Happiness & 299 & 15.18 & 16.00 & 16.00 & 3.90 & -.29 & -.49 & 4.00 & 22.00 \\
Depression & 299 & 5.75 & 4.00 & 1.00 & 5.49 & 1.42 & 1.38 & 0.00 & 25.00 \\
Psychosomatic sym. & 297 & 1.99 & 1.71 & 1.24 & 0.82 & 1.24 & 1.13 & 1.00 & 5.00 \\
\hline
\end{tabular}


Table 3.

Differences in the quality of life in relation to the traumatic loss respondent subcategory

\begin{tabular}{lllllll}
\hline Quality of life & & $\mathrm{N}$ & $\mathrm{AS}$ & $\mathrm{SD}$ & $\mathrm{F}_{(2,296)}$ & $\mathrm{p}$ \\
\hline \multirow{3}{*}{ Life Satisfaction } & $\mathrm{NL}$ & 99 & 21.86 & 6.89 & & \\
& $\mathrm{FD}$ & 100 & 16.81 & 6.78 & 44.67 & .001 \\
& $\mathrm{FM}$ & 100 & 13.28 & 5.55 & & \\
Subjective Happiness & $\mathrm{NL}$ & 99 & 17.01 & 2.82 & & \\
& FD & 100 & 15.66 & 4.03 & 35.59 & .001 \\
& FM & 100 & 12.89 & 3.58 & & \\
\hline
\end{tabular}

Respondent group: FM - family of the missing; FD - family of the deceased; NL - no loss

In examining the role of social support, we were interested in the frequency of specific forms of support, as well as its significance for the respondents who experienced loss in the war. The response frequencies presented in Table 4 indicate that the support of the family $\left(f_{(F D)}=82, f_{(F M)}=85\right)$, followed by that of friends $\left(f_{(\mathrm{FD})}=77, \mathrm{f}_{(\mathrm{FM})}=65\right)$, was the most frequent and useful in the wake of loss, while other types of social support were less represented in terms of frequency (state support: $\mathrm{f}_{(\mathrm{FD})}=32, \mathrm{f}_{(\mathrm{FM})}=34$; professional support: $\left.f_{(F D)}=21, f_{(F M)}=25\right)$. Respondents who used professional support in overcoming their loss rated it as useful $\left(\mathrm{f}_{(\mathrm{FD})}=16, \mathrm{f}_{(\mathrm{FM})}=19\right)$ in most cases. It can also be pointed out (Table 4) that the respondents from the category of the families of the missing assessed the support of the state as less useful compared to the respondents whose family members had died.

Table 4.

Frequency and percentage of respondents' responses with regard to the type of support and its usefulness (support received)

\begin{tabular}{lrrrr}
\hline \multirow{2}{*}{ Type of support } & \multicolumn{2}{c}{ Group } & \multicolumn{2}{c}{ Benefits of support } \\
\cline { 2 - 5 } & FD & FM & FD & FM \\
\hline Support of the family & $82 / 82.0$ & $85 / 85.9$ & $79 / 97.5$ & $79 / 92.9$ \\
Support of friends & $77 / 77.0$ & $65 / 66.3$ & $70 / 92.1$ & $46 / 70.8$ \\
Support of the state & $32 / 32.0$ & $34 / 34.7$ & $16 / 51.6$ & $11 / 32.4$ \\
Professional support & $21 / 21.2$ & $25 / 25.8$ & $16 / 64.0$ & $19 / 70.3$ \\
\hline
\end{tabular}

Respondent group: FM - family of the missing; FD - family of the deceased

The role of social support was tested through two multiple regression analyses - the first with respect to total social support (which included social, state and professional support) and the second with respect to family support. The results of the first procedure show that social support is a significant predictor of life satisfaction. In other words, the people who have received higher levels of social support are more satisfied with life. Social support doesnot appear to be a significant predictor of depression, psycho- 
somatic symptoms, and the degree of subjective happiness. A statistically significant model was obtained, explaining about $8 \%$ of the variance of the criteria $(\mathrm{R}=.29 ; \mathrm{R} 2=.08 ; \mathrm{F}(4,192)=4.25 ; \mathrm{p}<.01)$. The obtained results are shown in Table 5 .

Table 5.

Prediction of total social support through depression, psychosomatic symptoms, life satisfaction and subjective happiness

\begin{tabular}{|c|c|c|c|c|c|c|}
\hline & $\mathrm{B}$ & Beta & $\mathrm{T}$ & $\mathrm{p}$ & $\mathrm{R}$ & Part \\
\hline Depression & -.06 & -.20 & -1.70 & .09 & -.20 & -.12 \\
\hline Psychosomatic symptoms & .02 & .13 & 1.13 & .26 & -.12 & .08 \\
\hline Life Satisfaction & .09 & .30 & 2.88 & .00 & .25 & .20 \\
\hline Subjective Happiness & -.06 & -.14 & -1.39 & .16 & .12 & -.10 \\
\hline
\end{tabular}

In the following analysis (Table 6), a prediction of the support from immediate family members through depression, psychosomatic symptoms, life satisfaction, and subjective happiness was made. This type of support was singled out because family support proved to be the most common and significant form of support. This way, a statistically significant model was obtained, explaining about $14 \%$ of the variance of the criteria $(\mathrm{R}=.37$; $\mathrm{R} 2=.14$; $\mathrm{F}(4,192)=7.81 ; \mathrm{p}<.001)$. The results indicate that persons who, on the average, hada greater degree of support from immediate family members had lower depression on the average, which is also the only significant predictor of support from immediate family members.

Table 6.

Prediction of support by immediate family members through depression, psychosomatic symptoms, life satisfaction and subjective happiness

\begin{tabular}{|c|c|c|c|c|c|c|}
\hline & B & Beta & $\mathrm{T}$ & $\mathrm{p}$ & $\mathrm{R}$ & part \\
\hline Depression & -.03 & -.44 & -3.86 & .00 & -.34 & -.26 \\
\hline Psychosomatic Symptoms & .00 & .19 & 1.75 & .08 & -.20 & .12 \\
\hline Life Satisfaction & .01 & 17 & 1.69 & .09 & .26 & 11 \\
\hline Subjective Happiness & -.01 & -.09 & -.97 & .33 & .18 & -.07 \\
\hline
\end{tabular}

$\mathrm{R}=.37 ; \mathrm{R}^{2}=.14 ; \mathrm{F}_{(4,192)}=7.81 ; \mathrm{p}<.001$

The Kruskal-Wallis test also examined whether there were differences in the subjective consequences of the war depending on the category of loss of a close family member, i.e. whether there were differences in the presence of psychosomatic and depression symptoms (Table 7). The results show that, on the average, the family members of the persons missing during the war have the most severe depression and the highest psychosomatic symptoms. 
Table 7.

Differences in the subjective consequences of war in relation to the traumatic loss respondent subcategory

\begin{tabular}{llccccc}
\hline Variables & Group & N & Average rank & $\chi^{2}$ & $d f$ & $\mathrm{p}$ \\
\hline \multirow{3}{*}{ Depression } & NL & 99 & 119.95 & & & \\
& FD & 100 & 151.06 & 23.19 & 2 & .000 \\
& FM & 100 & 178.69 & & & \\
Psychosomatic Symptoms & NL & 99 & 116.43 & & & \\
& FD & 99 & 146.34 & 31.03 & 2 & .000 \\
& FM & 100 & 184.23 & & & \\
\hline
\end{tabular}

Respondent group: FM - family of the missing; FD - family of the deceased; NL - no loss

\section{Discussion}

The results of the present study have shown that the quality of life of the respondents varies greatly depending on whether they have suffered the loss of a close family member in the war or the war ended for them without a fatal outcome in the family. Significant differences have also been found between the group of respondents who buried their loved ones and the groups of those still waiting for information about what happened to the missing family members. The data have shown that the closest family members of those missing in the war whose remains have not yet been found have the lowest quality of life in terms of general satisfaction and a subjective sense of happiness, which is in favour of the stated supposition. People who have not experienced the loss of a close person have the highest satisfaction with life and the highest level of subjective happiness, while the respondents who lost a close family member but whose remains were found show a worse quality of life than those who did not experience the loss of a close person during the war, but are happier and more satisfied than the family members of missing persons.

The loss of a close family member is one of the most stressful and painful events a person can experience, especially if the loss was sudden and happened as a result of wartime violence. When a family suffers the loss of a loved one, it is necessary to adapt to new life circumstances through accepting that loss. Although it may take some time for the family to resume normal functioning, through cultural rituals and available social support that facilitate the grieving process, there is a gradual acceptance of the fact that life continues even when a significant person is no longer present. However, in the families of missing persons, where the loss is unclear and unresolved, accepting this loss is almost impossible and represents a complex emotional process. The thoughts of close family members are flooded daily with the questions about what happened to their close family members, how he or 
she disappeared; based on available information and their own opinions, they reconstruct the events. Aversive, past events are reconstructed through memories and supported with information (Alexander et al., 2004). This constant reconstruction of events determines the emotions and behaviour of the individual, but also of social groups (Alexander et al., 2014). Searching for new answers so that their story can have closure, and not finding them, the families of the missing almost completely lose confidence in the world around them. Regardless of the loss of trust, their hope that they will experience the knowledge of the truth endures. In addition to personal psychological trauma, the families of the missing live in the societies burdened with social trauma that is embedded in the collective consciousness and social identity of the community (Pedović and Hedrih, 2019).Social trauma is reinforced on a daily basis by the media and the political context of recalling wartime events and socialization twenty-five years after the formal cessation of the conflict. The context of living in a society burdened with social trauma helps maintain an affective connection with the missing person, but at the same time deepens the family's distrust of the world around them. In interviews with respondents in the research preparation phase, all respondents expressed distrust of the institutions' actions in the process of searching for missing persons, even to the extent that they felt that the institutions wanted the years to pass so that all the family members died to end the issue of missing persons. This distrust supports a constant cognitive focus on questions that do not contain answers.

Such a cognitive orientation does not allow the severance of effective attachments to the missing person and maintains an ambivalent attitude towards loss. In fact, it helps to maintain an affective bond and prevents the acceptance of loss, initiating the grieving process, and finding mechanisms for overcoming aversive life experiences (Bolwby, 1969; Fonagy and Allison, 2014). When the loss of a loved one implies his/her disappearance, affective attachment continues, and it is maintained by constant cognitive reconstruction of the events and life in the context of social trauma (Alexander et al., 2014; Boss, 1999, 2002).The point of sadness after the death of a loved one is for the people to "uncouple" from that person and thus continue to live their lives and begin to forge new relationships (Bolwby, 1969; Buckman, 1996). When people live in these conditions, it is expected that they cannot function normally and that all the characteristics of "ambivalent loss" impair their quality of life.

As we learned in the preparatory phase of the research, there were cases that after many years of searching, and the DNA analysis confirming with 99.9\% certainty the identification of the missing body, the family members, tired of the uncertainty of the information, did not want to sign the obtained findings and thus recognize the analysis as valid. This example points to the complexity of the grieving process due to a delay in accepting the loss. It is 
difficult to be content with life and feel happy when there is great emptiness in a person and the inability to say goodbye to a loved one in the way that everyone deserves. Funeral rituals are very significant in the grieving process and greatly facilitate this process (Bowen, 1991; Bowlby, 1969). Missing families are unable to perform rituals and, therefore, accepting the loss is very difficult. Understanding such loss is an extremely complex psychological phenomenon, which raises the research question of emotional dynamics due to ambivalent loss.

One of the aims of this research was to predict the impact of social support on the quality of life (life satisfaction and the degree of subjective happiness) and the presence of depression and psychosomatic symptoms, as important aspects of mental health and indicators of the subjective consequences of war. The data obtained partly justified the assumption made above, indicating that a higher level of social support received, involving the immediate and wider family, friends, relevant institutions, families with similar problems, professional support and support from non-governmental organizations, results in increased life satisfaction; this model explains $8 \%$ of the criteria variance. However, social support did not prove to be a significant predictor of depression, psychosomatic symptoms, and subjective happiness. Although there is a large part of variance that remains unexplained, it can still be observed that social support has impact on certain aspects of the quality of life. According to Herman (2012), individuals without social support who experience the loss of a loved one can remain "trapped" in the grieving process, which greatly affects the mental health of the individual and, consequently, the quality of life. Social support helps not only to accept the loss, but also to establish affective connections with other close family members (for example, with other children or the children of the person we have lost).The support of others offers us some form of security and gives us the impression that there is someone there to protect us from the bad things that are happening to us (Başoğlu et al., 2005; Bowlby, 1969).Individuals who have experienced the loss of a close family member primarily need emotional support, love, understanding and companionship. This kind of support is usually received from our loved ones - family and friends (Lakey and Cohen, 2000). Most of the respondents cited family as the most frequent and significant form of support. For this reason, a prediction was made regarding the support received by immediate family members and the level of the quality of life and subjective consequences of war. This model explains $14 \%$ of the variance of the criteria, with family support proving to be a significant predictor of depression, while significant data were not obtained for life satisfaction, subjective happiness, and psychosomatic symptoms. People who had more support from their family had, on the average, fewer depressive symptoms, indicating the importance of understanding and being present in the process 
of coping with difficult life situations. Significant relationships are developed within the family circle that provides a sense of closeness, protection and security, and such interactions are a protective factor when facing life's difficulties and problems (Zvizdić, 2015). As already established, the support of the loved ones improves the quality of mental health.

Support from the state and relevant institutions is certainly a form of support that could have an impact on improving the living conditions. However, the results show that only $32 \%$ or $34.7 \%$ of the respondents stated that they had this form of support available. When it comes to mental health and the presence of depression and psychosomatic symptoms, a very important form of support would be professional support, which only $21.2 \%$ or $25.8 \%$ of respondents chose in this case. However, those that received professional support found it useful. The obtained results of the research regarding psychosomatic symptoms can also be related to the average age of respondents (over 55 years) -it is possible that certain psychosomatic symptoms such as high or low blood pressure, shortness of breath, headaches, and others, are correlated with age, as well as some other chronic illnesses. Therefore, it is certainly necessary to select more consistent mental health indicators in future research. Nevertheless, the results of the research confirm that there are differences between the examined groups with regard to the loss experienced, although the average age of the examined groups is approximately the same.

The support of the family and other loved ones is an important, but not the only, factor that contributes to improving a person's quality of life and mental health. For the impact to be much greater, there needs to be a whole community support network that offers help, understanding and acceptance in every sense, but a support network must be available and the motivation to participate in it must be seriously worked on. The results of other studies have shown that the presence of social support through family, friends and other external sources of support outside the family and the immediate environment is a significant protective factor in dealing with adverse life situations, which has an important effect on the quality of mental and physical health (Heaney and Israel, 2008; Lakey and Cohen, 2000; Zvizdić, 2015). However, the role of social support has not been detected by this research. Most of the respondents did not use other forms of support such as support from professionals, support from organizations or available services of state institutions, which made it impossible to obtain valid results. The reasons for under-utilization of support services may lie in cultural and political circumstances, educational attainment, lack of confidence, lack of information, unequal access to various forms of support, insufficient motivation to participate and other reasons. Therefore, further empirical attention is needed to address the role of social support for persons facing specific traumatic processes. 
The study was conducted on a convenient sample and hence it is not possible to apply the obtained results to the whole population. In addition, accurate information on the number of missing persons and their family members is a more of a phenomenological piece of information that is brought more into the day-to-day political context than it is an official piece of information that is trustworthy. The obtained findings indicate the need to investigate the deeper consequences of the war on mental health, e.g. anxiety spectrum symptoms, the presence of post-traumatic symptoms, and other forms of psychological distress not covered by this study. The results of the research raise the issue of the complexity of the emotional dynamics of "ambivalent loss" and the role of affective attachment to the missing person, because they leave a clear conclusion about the mental health and quality of life of the families who experienced loss during the war. It would also be useful to look at the measured variables in relation to the socio-demographic characteristics of the sample: gender, age, educational level, employment status and material status, as well as kinship with the missing person. Especially important are the issue of kinship with the missing person and the research of emotional factors of the traumatic loss with the possibility of transmission to the descendants or younger generation. At the same time, such a question imposes the need to explore the relationship between social trauma (regardless of the insufficient empirical research of this concept) and the process of grieving due to ambivalent loss, but also the role of social trauma, its integration into the collective consciousness and social identity and its impact on the emotional processes of specific groups in post-war societies. It is necessary to further investigate the subjective consequences of wartime life and socialization in the post-war societies in which latent war socialization takes place on both the media and socio-political scene, and where the distrust of the vulnerable categories of the population towards the society at large is especially evident.

The preparatory phase of the research for the first two categories of respondents was followed by the expression of the emotion of remembering and mourning, which was manifested through the tendencies of the respondents to tell the interviewer their story, to express disappointment, dissatisfaction and distrust towards the relevant authorities, to express hope, but also to be pleased that "someone remembered" to record their suffering and pain. It is precisely this impression that supports the need for a serious dedication to the motivational aspect of treatment with psychological support to families in dealing with the loss of missing persons, but also to the mentalisation of aversive experiences from the past (Fonagy and Allison, 2014). The effect of social support remains the main perplexity of this 
research; therefore, it would be more appropriate to examine in depth its impact on various aspects of the quality of life for the family members who face a real inability to initiate the grieving process, especially in the aspect of distrust of families towards state policies. The results of this research support the existence of an intertwined link between traumatic loss in the war, impaired mental health and the quality of life, and the untapped opportunity for professional support as a significant resource for overcoming loss and overcoming the vicious circle of the disturbed trust in the world around us. Trauma is a universal phenomenon and the results of this study may be implicated in other post-war communities. Finally, an empirical test points to the need of finding a specific psychological support programme for the persons facing long delays in the grieving process. It is necessary to apply humane ways of acknowledging suffering and pain, so that even the families that cannot find their missing family members have a chance for a better quality of life and the preservation of mental health.

\section{Conclusion}

Unlike the families who experienced the loss of a close family member in the war and had the opportunity to say goodbye to their loved ones or the persons who experienced wartime life and socialization, but not loss, the families whose close family members are missing as a result did not get a chance to start of the grieving process. Their life is characterized by the constant maintenance of affective attachment to the missing person, life in the context of social and personal trauma, by the hope and desire to welcome a day when they will be able to bury their loved ones, while all other wishes and desires in their life are latent, marginalized or sporadic. Considering that the whole process of delaying grief has taken twenty-five years and has left an indelible mark on their quality of life and mental health, it is necessary to find adequate forms of psychological support, as well as social mechanisms that will incorporate humanity into political culture and collective will. Psychological support of the families searching for their missing persons in the war should be aimed at the acceptance of the missing persons' physical absence from family life, the establishing and recognizing of the importance of new affective relationships, and the building of a resilient attitude towards life in the context of social trauma and the constant creation and maintenance of cognitive constructs of disappearance scenarios. Special attention should also be paid by the professional public to the motivational aspects issue of family participation in psychological treatments. 


\section{References:}

Alexander, J. C., Eyerman, R., Giesen, B., Smelser, N. J., Sztompka, P. (2004). Cultural Trauma and collective identity. California: University of California Press.

Başoğlu, M., Livanou, M., Crnobarić, C., Frančišković T., Suljić, E., Đurić D., Vranešić, M. (2005). Psychiatric and Cognitive Effects of War in Former Yugoslavia. JAMA, 294(5), 580-590.

Batista-Pinto Viese, E. (2010). Culture and Migration: Psychological Trauma in Children and Adolescents. Traumatology, 16(4), 142-152.

Betz, G., Thorngren, J. M. (2006). Ambiguous Loss and the Family Grieving Process. The Family Journal, 14(4), 359-365.

Bjornsson, A. S., Hardarson, J. P., Valdimarsdottir, A. G., Gudmundsdottir, K., Tryggvadottir, A., Thorarinsdottir, K., et al. (2020). Social trauma and its association with posttraumatic stress disorder and social anxiety disorder. Journal of Anxiety Disorders, 72, 1-9.

Boss, P. (1999). Ambiguous loss: Learning to Live with Unresolved Grief. London: Harvard University Press.

Boss, P. (2002). Ambiguous loss: Working with families of the missing. Family Process; Rochester,41(1), 14-17.

Bowen, M. (1991). Family reactions to death. In F. Walsh i M. McGoldrick (Eds), Living beyond loss: Death in family (p. 335-348). New York: Norton.

Bowlby, J. (1969). Attachment and loss. New York: Basic Books.

Buckman, R. (1996). Ne znam što reći. Kako pomoći i podržati umiruće. Zagreb: Institute of Graphic Arts of Croatia.

Diener, E. D., Emmons, R. A., Larsen, R. J. (1985). The satisfaction with life scale. Journal of personality assesment, 49(1), 71-75.

Fonagy, P., \& Allison, E. (2014). The role of mentalizing and epistemic trust in the therapeutic relationship. Psychotherapy, 51(3), 372-380.

Frye, J. S., Stockton, R. A. (1982). Discriminant analysis of posttraumatic stress disorder among a group of Vietnam veterans. American Journal of Psychiatry, 139(1), 52-56.

Hadžić, A. (2019). Uvod: O traumi. U M. Tomašević i T. Mirović (Ed.), Trauma naša priča (p. 19-42). Belgrade: Shema therapy Center.

Hamburger, A., Hancheva, C., Özcürümez, S., Scher, C., Stankovic, B., Tutnjevic, S. (2018). Forced Migration and Social Trauma - Interdisciplinary Perspectives from Psychoanalysis, Psychology, Sociology and Politics. London: Routlege.

Haskell, L., Randall, M. (2009). Disrupted attachments: A social context complex trauma framework and the lives of Aboriginal peoples in Canada. Journal of Aboriginal Health, 5(3), 48-99.

Heaney, C. A., Israel, B. A. (2008). Social networks and social support. Health behavior and health education: Theory, research and practice, 4, 189-210.

Herman, J. L. (2012). Trauma i oporavak. Novi Sad: Psihopolis institute. 
Hutchinson, E., \& Bleiker, R. (2015). Grief and the transformation of emotions after war. In L. Ahäll \& T. Gregory (Eds.), Interventions. Emotions, politics and war (pp. 210-221). Abingdon, Oxon: Routledge.

ICRC (2019). Još 7000 nestalih života: Porodice nestalih osoba u Bosni i Hercegovini [Brochure]. Sarajevo: ICRC

Jovanović, V. (2016). Psihologija subjektivnog blagostanja. Novi Sad: Faculty of Philosophy.

Keilson, H., Sarphatie, H. R., (1992).Sequential traumatization in children: A clinical and statistical follow-up study on the fate of the Jewish war orphans in the Netherlands. Jerusalem: Magnes Press.

Kroenke, K., Spitzer, R. L. (2002). The PHQ-9: A new depression diagnostic and severity measure. Psychiatric Annals, 32(9), 1-7.

Kroenke, K., Spitzer, R. L., Wiliams, J. B. (2001). The PHQ-9: validity of a brief depression severity measure. Journal of General Internal Medicine, 16(9), 606-613.

Lakey, B., Cohen, S. (2000). Social support theory and measurement. In S. Cohen, L. Underwood and B. H. Gottlieb (Eds), Social support measurement and intervention: a guide for health and social scientists(p. 29-52). New York: Oxford University Press.

Lyubomirsky, S., Lepper, H. S. (1999). A measure of subjective happiness: Preliminary reliability and construct validation. Social indicators research, 46(2), 137-155.

Milosavljević, B. (2000). Djeca u ratu i poslije rata, psihološka istraživanja. Banja Luka: National and University Library of the Republic of Srpska "Petar Kočić" and Center for Development and Evaluation of Psychosocial Programs - Department of Psychology, Faculty of Philosophy.

Milosavljević, B. (2003). Djeca i ratne traume, socijalnopsihološki aspekt $i$ istraživanja. Banja Luka: Faculty of Philosophy.

Pedović, I., Hedrih, V. Social trauma and emotional attachment (2019) . Facta Universitatis, Series: Philosophy, Sociology, Psychology and History, 18(1), 27-37.

Subotić, S. (2014). Evaluacija inkluzivne obrazovne reforme u osnovnoj školi. (Unpublished PHD dissertation). Novi Sad: Faculty of Philosophy, Novi Sad University.

Thoits, P. A. (2011). Mechanisms Linking Social Ties and Support to Physical and Mental Health. Journal of Health and Social Behavior, 52(2), 145-161.

Werner-Lin, A., Moro, T. (2004). Unacknowledged and stigmatized losses. In F. Walsh i M. McGoldrick (Eds), Living beyond loss: Death in the family(p. 247-272). New York: Norton.

Zvizdić, S. (2015). Socijalna podrška i rezilijencija kod djece i adolescenata. Sarajevo: Sarajevo Faculty of Philosophy. 


\title{
Kvalitet života nakon traumatskog gubitka i uloga socijalne podrške - ispitivanje psiholoških posljedica rata dvadeset pet godina poslije
}

\section{Sanja Radetić Lovrić}

Univerzitet u Banjoj Luci, Filozofski fakultet, Odsjek za psihologiju

\author{
Aleksandra Pećanac \\ Nova banka, a.d. Banja Luka
}

Istraživanje je sprovedeno s ciljem spoznaje dalekosežnosti psiholoških posljedica rata, koji se vodio na prostoru bivše Jugoslavije (1991-1995). Istraživanje ispituje relacije između doživljenih ratnih stresora i ratnog traumatskog iskustva gubitka, kvaliteta života i mentalnog zdravlja, kao i ulogu socijalne podrške između tri kategorije ispitanika: prvu čine ispitanici kojima je u ratu nestao blizak član porodice, a čiji posmrtni ostaci nisu pronađeni do danas; drugu kategoriju čine osobe koje su izgubile bliskog člana porodice u ratu; dok treću kategorijučine ispitanici koji su učestvovali u ratnoj socijalizaciji, ali nisu doživjeli gubitak bliskog člana porodice $\mathrm{u}$ ratu. $\mathrm{U}$ istraživanjusu korištene lista psihosomatskih simptoma, upitnik depresivnih simptoma, Skala subjektivne sreće, Skala zadovoljstva životom i skala procjene značaja socijalne podrške. Rezultati pokazuju da ispitanici koji i dalje tragaju za tijelom nestalog člana porodice imaju niži kvalitet života u odnosu na druge dvije kategorije ispitanika i imaju izraženije prisustvo depresivnih i psihosomatskih simptoma. Uloga socijalne podrške u procesu oporavka od traume ostaje nejasna. Rezultati istraživanja su prodiskutovaniu odnosu na okončan i produžen traumatski gubitak, a upućuju na dalje istraživanje kompleksne emocionalne dinamike kao posljedice ratne socijalizacije.

Ključne riječi: trumatski gubitak, stresori, kvalitet života, socijalna podrška, nestale osobe 